\title{
植物开花生热的生物功能及其调控机制研究进展
}

\author{
张出兰 ${ }^{(12)}$, 王若涵 ${ }^{(1 *}$, 张志翔 ${ }^{(12)}$, 程和平 ${ }^{(3)}$ \\ (1) 北京林业大学生物科学与技术学院, 北京 100083 ; \\ (2) 北京林业大学自然保护区学院, 北京 100083 ; \\ (3) 北京大学分子医学研究所, 北京 100871 \\ * 联系人, E-mail: wangrh@bjfu.edu.cn
}

2015-07-02 收稿, 2015-08-30 接受, 2015-10-15 网络版发表

中央高校基本科研业务费专项资金(YX2014-14)和国家自然科学基金(31100450, J1103516)资助

摘要 开花生热是某些植物科属在长期进化过程中形成的一项重要适应机制, 有助于植物花 器官抵御低温伤害, 并且能够促进昆虫访花和传粉受精, 对于确保植物的生殖成功具有重要的 生物学意义. 本文基于国内外近年来植物开花生热研究方面取得的重要进展, 结合开花生热活 体实时检测的技术发展, 对植物开花生热的类型、生物学功能以及调控机制进行综述, 并展望 了植物开花生热研究领域函待解决的重要问题.

关键词

开花生热 红外成像 交替氧化酶 解偶联蛋白 miRNA 植物的开花生热效应(floral thermogenesis)是指 一些植物类群在开花繁殖过程中, 花器官能够自主 地产生热量, 并可以对自身温度加以调控 ${ }^{[1]}$, 使花部 温度明显高于周围环境温度, 从而促使生殖发育顺 利完成的现象 ${ }^{[2,3]}$. 尽管植物的所有器官在新陈代谢 活动中, 均能产生一些热量, 但是, 在大多数植物 中, 这种生热反应表现非常缓慢, 或是热量释放很 少, 因而没有明显的温度上升 ${ }^{[4]}$. 与此不同的是, 开 花生热植物的花器官在短期内能够产生大量热量, 从而提高花部温度, 有的甚至使花器官与环境温差 高达 $35^{\circ} \mathrm{C}$, 如臭菘 (Symplocarpus foetidus $)^{[5,6]}$. 越来 越多的研究表明, 开花生热在植物生殖发育过程中, 具有多样的生物学功能: 开花生热不仅可以防止花 器官遭受低温伤害 ${ }^{[7]}$, 还可以直接以热能回报 (heat reward)的形式来增加吸引昆虫访花的筹码, 即产生 的热量吸引昆虫在花内停留, 使其得以汲取能量进 行交配或飞行等活动 ${ }^{[8]}$; 甚至可以通过促进花香的 释放, 进而吸引昆虫访花 ${ }^{[9,10]}$. 因此, 开花生热是植 物抵御外界不良环境和主动促进生殖成功的有效适 应对策, 在生殖发育过程中具有重要的生物学功能
和意义, 近年来已成为国际上植物功能研究领域中 的一个热点问题, 备受植物生物学研究者的重视.

近年来, 随着研究技术的进步, 植物开花生热的 研究取得了显著的进展. 高分辨率的红外活体成像 技术(infrared thermography)的广泛应用，使得研究者 能够更加精确地了解植物开花生热的表型和生热过 程. 并且, 高通量技术的发展, 尤其是气相色谱-质 谱联用 (gas chromatography-mass sepetrometry, GCMS)分析以及转录组测序、miRNA测序等高通量测序 技术的应用, 为开花生热调控机制的研究带来了便 利. 由于这些先进技术的广泛应用, 开花生热的生物 学功能及其调控机制等方面的研究也取得了较为重 要的进展. 本文综合近年来开花生热研究领域的主 要研究进展, 对植物开花生热的表型、生物学功能及 其调控机制进行综述, 并展望了这一领域亟待深人 研究的科学问题.

\section{1 开花生热的精确检测及生热类型}

植物中的开花生热现象最早由法国博物学家 Jean-Baptiste Lamarck于1778年在海芋属(Arum spp.) 
植物中发现 ${ }^{[11]}$. 然而由于植物生热是一个连续变化 的动态过程, 释放的能量无法瞬时捕获, 加之外界自 然环境的温度波动干扰, 在早期缺乏有效技术手段 的情况下, 一直无法实现开花生热中花器官能量释 放和温度变化的实时测定和动态记录. 随后, 有研究 发现温度在生热的花中是不均匀分布的, 由此推测 并不是整个花朵都具有生热的能力, 生热是由花器 官的特定组织产生. 然而, 在寒冷的自然环境中, 开 花生热所产生的这些毫瓦级 $(\mathrm{mW})$ 的热量散失很快, 用常规的温度记录方式, 无法达到快速记录温度变 化的目的, 也就无法精确地定位生热的发生部位和 发生过程. 直到红外线成像技术的发明和应用, 使得 植物开花生热的研究在表型观测上实现了质的飞跃, 进而为实现后续的深人研究奠定了重要的基础.

红外线 (infrared rays) 是太阳光谱中诸多不可见 光线中的一种, 其波长大于可见光, 约为 0.75 $1000.00 \mu \mathrm{m}$. 红外线可包含3部分, 即近红外线, 波 长为 $0.75 \sim 1.50 \mu \mathrm{m}$; 中红外线, 波长为 $1.50 \sim 6.00 \mu \mathrm{m}$; 远红外线, 波长为 $6.00 \sim 1000.00 \mu \mathrm{m}$. 红外成像技术 最早被应用于军事需求, 其通过传感器捕获物体所 发射的红外线, 进而通过光谱成像仪成像实现实时 动态的红外影像 ${ }^{[12]}$. 随着高分辨率红外成像系统的 发展，该技术作为一种无损伤活体检测手段，已经在 多领域中被广泛用于检测温度变化和定位热量释放.

红外成像技术于 20 世纪 90 年代开始被用于植物 的开花生热研究 ${ }^{[13]}$. 植物在开花生热时, 花器官释 放大量热量, 从而发出红外线. 通过红外成像技术, 人们在一些生热植物中确定了主要的开花生热部位, 例如, 雌莣群为木兰科植物玉兰花器官的主要生热 部位 ${ }^{[14]}$, 天南星科臭菘 $(S$. foetidus)生热主要来源于 肉穗花序的上部 ${ }^{[15]}$, 而天南星科大野芋 (Colocasia gigantean)开花生热的主要部位则是位于肉穗花序下 部的退化雄莣 ${ }^{[16]}$. 近来, 随着光学和红外技术的发 展, 本研究组通过加载微距镜头, 成功实现了生热植 物体的红外微距成像, 提高了红外成像的分辨率(图 1). 这一技术进展大大提高了对植物开花生热组织 定位的准确性. 近年来, 科学研究力求在最接近生理 活性状态下, 对生命本质进行探索, 无损伤活体检测 技术在植物研究中的重要性日益凸显. 本研究组在国 际上率先将红外成像技术与热偶探针(直径 $0.5 \mathrm{~mm}$, 成 像时间 3 5 s) 相结合, 实现了对于植物花部温度瞬时 变化的红外成像以及瞬时热量捕获, 为活体红外
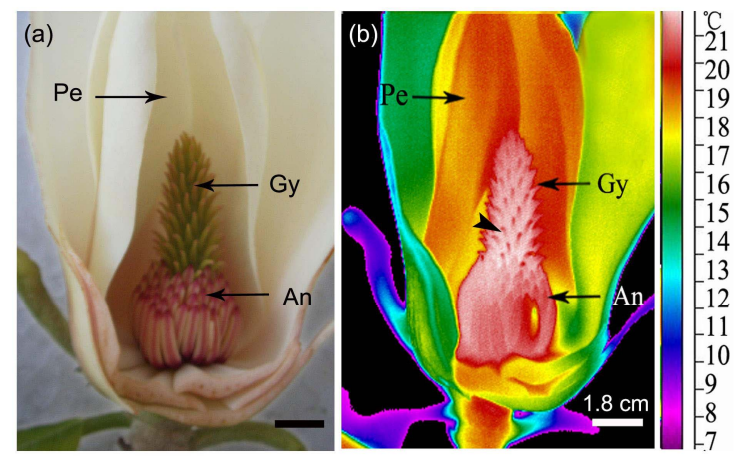

图 1 (网络版彩色)开花生热时期玉兰花部器官的实景(a)和红外线 成像(b)图片(改自文献 14)。红外成像图片(b)中颜色梯度表示不同的 温度, 具体温度数值见右侧的温度标尺. 短箭头所指区域为花部主 要生热部位. Pe: 花被片; Gy: 雌芯群; An: 雄芯群

Figure 1 (Color online) Ture color photograph (a) and infrared thermal image (b) of the thermogenic flower (modified from references 14). The scale in figure (b) indicates the temperature range. The short arrowsindicate the thermogenic part. Pe: petals; Gy: gynoecium; An: androecium

成像在植物中的应用研究开辟了更精确测定的新途 径 ${ }^{[10,14]}$. 并且在木兰科植物开花生热的研究中, 成功研 制了适合于植物实时活体动态观测的微距镜头，从而 实现了木兰科植物花器官生热部位的准确界定 ${ }^{[14]}$.

开花生热植物具有不同的生热模式(图2). 有的 开花生热植物在花期产生的热量, 能够将花器官的 温度维持在相对恒定的范围内，使花部温度不随外 界环境温度波动而变化(图2(a))。这种生热模式为生 热调控型 (thermoregulation). 莲科的荷花 (Nelumbo

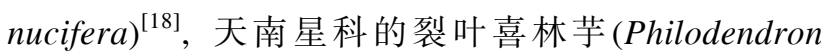
selloum $)^{[19]}$ 和臭菘 $(S . \text { foetidus })^{[20]}$ 等均属于这一类型. 此外, 还有些开花生热植物, 尽管花部温度始终高于 环境温度，但不能保持恒定，而是随着外界环境温度 变化, 有生热高峰值的曲线变化(图2(b)), 如天南星

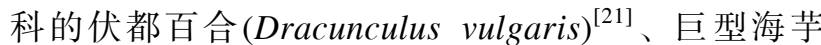

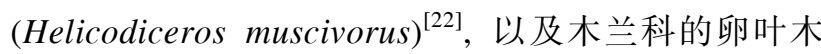
兰 $($ Magnolia ovata $) 、$ 玉兰 $(M$. denudata $)$ 、武当木兰 $(M$. sprengeri $)^{[10,14,23]}$. 这一生热类型为假生热调控型 (pseudo-thermoregulation). 在气候变化多端的自然环 境中, 开花生热植物在与环境协同进化过程中形成 了上述不同的生热类型. 从能量利用角度看, 假生热 调控植物似乎以更少的热量消耗获得生殖成功，更 符合植物的有效能量分配.

此外，生热类型与访花昆虫的习性存在着密切 关系，如木兰科植物武当木兰 $(M$. sprengeri $)$ 具有两 个生热高峰, 分别发生在花香浓郁的雌苑成熟期和 


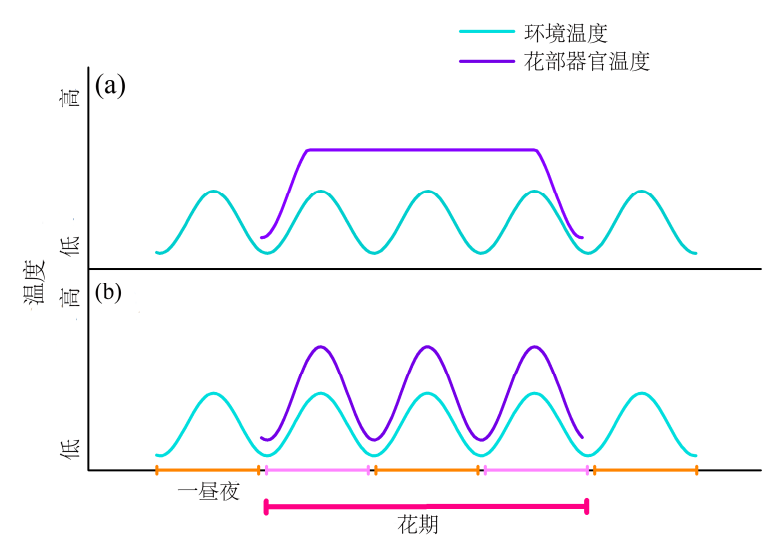

图 2 (网络版彩色)植物开花生热的类型(改自 [17]). (a) 生热调控 (thermoregulatory)生热类型; (b) 假生热调控 (pseudo-thermoregulatory)生热类型

Figure 2 (Color online) Different patterns of heat production in thermogenic flowers (modified from [17]). (a) Thermoregulatory pattern; (b) pseudo-thermoregulation pattern

雄芯成熟期 ${ }^{[10]}$. 露尾甲属昆虫(Epuraea sp., Nitidulidae) 作为其有效传粉昆虫, 其访花高峰巧妙地与白天的生 热高峰相重合. 而值得注意的是, 在夜间开花的木兰 科植物中卵叶木兰 $(M$. ovata $)$ 和塔毛利帕斯木兰 $(M$. tamaulipana), 生热高峰发生在夜晚, 其访花昆虫方头 甲属昆虫(Cyclocephala, Scarabaeidae)则表现为夜间访 花习性 ${ }^{[23-25]}$. 因此, 为了最大限度地促进生殖成功, 虫 媒植物采用各种策略吸引访花昆虫为其传粉. 尽管目 前已发现植物的生热类型与有效传粉昆虫的访花习
性具有极大的相关性，但是这其中的协同进化机制还 需要进一步的科学试验和数据支持.

\section{2 开花生热在生殖生物学中的重要作用}

开花生热不仅可以防止花部器官遭受低温伤害, 而且在传粉生物学, 特别是植物与昆虫之间的互作关 系中扮演着重要角色 ${ }^{[7,9]}$. 有研究者认为花部产生的热 量可以直接以热能的形式提供给访花昆虫 ${ }^{[5,8]}$, 在某种 程度上是对昆虫的一种直接能量的回报. 也有研究发 现，在植物开花生热的高峰期花香浓郁，主要花香成 分含量有明显的增加 ${ }^{[10,26]}$; 生热结束时, 香气也随着变 淡直至消失. 这表明香味的释放与花部生热存在着密 切联系. 因此, 开花生热还有可能通过促进花香的释 放，吸引昆虫访花. 通过大量的综合研究，这一假说已 经在木兰科植物中被证实 ${ }^{[10]}$.

近年来，本研究组首先使用红外成像与热偶探针 相结合的技术，发现了早春开花的木兰科植物武当木 兰 $($ M. sprengeri $)$ 具有开花生热效应. 在使用高分辨率 红外成像系统对生热组织进行准确定位的基础上, 进 一步持续观测了开花期间生热组织的温度变化. 其花 部的生热部位主要是雌芯群, 生热类型为假生热调控 (pseudo-thermoregulation), 具有两个显著的生热高峰, 分别发生于雌芯成熟期和雄芯成熟期(图3). 生热高峰 期与传粉昆虫访花时间完全一致. 更有趣的是，花香 有机挥发物(volatile organic compounds)的GC-MS分析

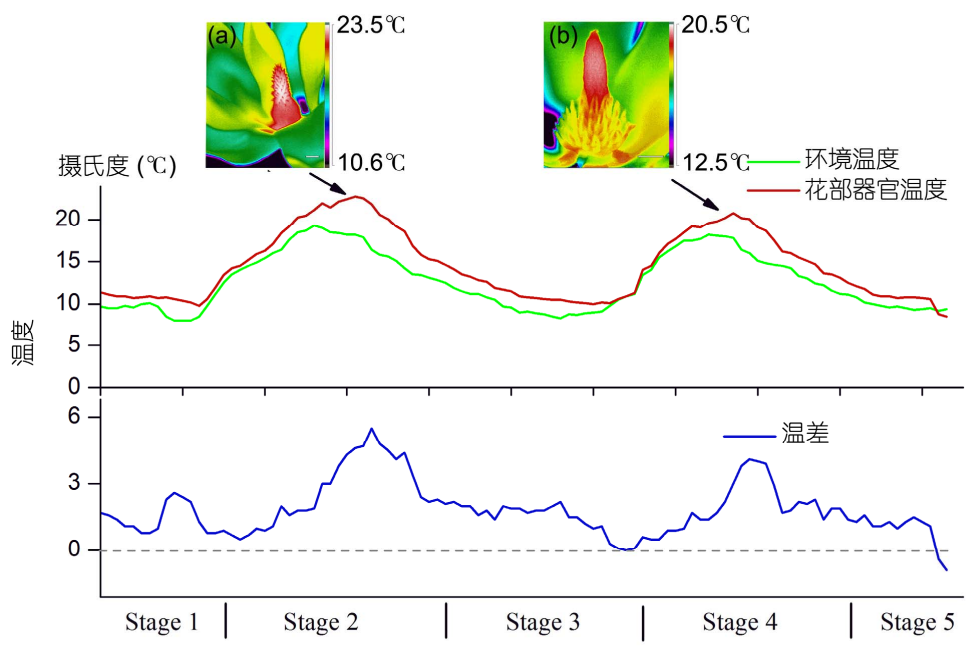

图 3 (网络版彩色)武当木兰(M. sprengeri)开花生热中的温度动态变化(改自文献[10]). 开花生热过程包括 4 个阶段: 阶段 1, 花蕾期(生热前期); 阶 段 2, 雌芯期(生热高峰 I ); 阶段 3, 雄蕊前期; 阶段 4, 雄惢期(生热高峰 II ). 图中的生热图片a, b 分别为雌蕊期和雄芯期的红外成像图片

Figure 3 (Color online) Changes in temperatures of M. sprengeri during floral thermogenesis (modified from Ref. [10]). Floral thermogenesis including 4 stages: stage 1, pre-pistillate; stage 2, pistillate; stage 3, pre-staminate; stage 4, staminate. (a) and (b) are Infrared thermal images of pistillate and staminate stage 
表明，两个高峰时期的花香成分高度相似，揭示了 玉兰花具有花香模拟(odour mimicry)机制, 即雌芯阶 段的花朵模拟雄芯阶段花朵的花香成分, 以吸引传 粉昆虫访花. 鉴于雌苑期的玉兰花不能为昆虫提供 花粉回报, 其花香模拟机制可以促使相同的传粉 昆虫访问雌萝和雄萝阶段的花朵, 对于其顺利授 粉极其重要 ${ }^{[10]}$. 综上, 在气候变化多端的自然环境 中, 开花生热无疑是植物抵御外界不良环境, 促进生 殖成功的一种适应对策, 是植物与环境长期协同进 化的结果 ${ }^{[27]}$, 在生殖发育过程中具有重要的生物学 意义.

\section{3 植物开花生热的调控机制}

尽管对于开花生热现象的生物学功能, 已有了 较为统一的看法, 但是对其内部调控机制的认识却 一直存在争议. 早期研究发现交替氧化途径可能在 开花生热中起作用 ${ }^{[28,29]}$. 交替氧化酶(alternative oxidase, AOX) 是一种植物细胞中广泛存在且定位于线 粒体内膜的末端氧化酶, 其介导的交替氧化途径是 线粒体电子传递链(electron transport chain, ETC)复合 物 III (细胞色素 $b c 1$ ) 和复合物 IV (细胞色素 $c$ 氧化酶)的
旁路 ${ }^{[30,31]}$.

在电子传递链主路, 即细胞色素途径中, 三羧酸 循环产生的还原型烟酰胺腺嘌呤二核苷酸(reduced form of nicotinamide-adenine dinucleotide, NADH)和 琥珀酸分别将电子传递给复合物 I (NADH脱氢酶)和 复合物 II (琥珀酸脱氢酶). 复合物 I 和复合物 II 将电 子传递给泛醌，再经由复合体 III 传递给复合体 IV, 最 终将电子传递给 $\mathrm{O}_{2}$, 并将其还原为 $\mathrm{H}_{2} \mathrm{O}$. AOX介导的 交替氧化途径则可以使电子绕过复合体 III 和 IV，而 经由泛醌传递给 AOX, 再由 AOX传递给 $\mathrm{O}_{2}{ }^{[31,32]}$. 在 电子传递的过程中, 复合体 I , III, IV 都会将线粒体 基质中的 $\mathrm{H}^{+}$䈋出到线粒体内膜与外膜之间的膜间隙. 由于线粒体内膜对质子是不通透的, 这些质子的转 移会导致线粒体基质与膜间隙之间产生跨膜质子电 化学势梯度. 线粒体内膜上的ATP合酶(ATPase) 则可 以利用这一质子电化学势梯度, 将质子通过ATP合酶 (ATPase)返回线粒体基质而释放的自由能用于合成三 磷酸腺苷(adenosine triphosphate, ATP). 在交替氧化 途径中, 由于电子传递不通过复合体 III 和 IV, 而是直 接由 AOX传递给氧气, 并将 $\mathrm{O}_{2}$ 还原成 $\mathrm{H}_{2} \mathrm{O}$ (图4).

$\mathrm{AOX}$ 是一种二铁基羧化蛋白, 具有一个保守的

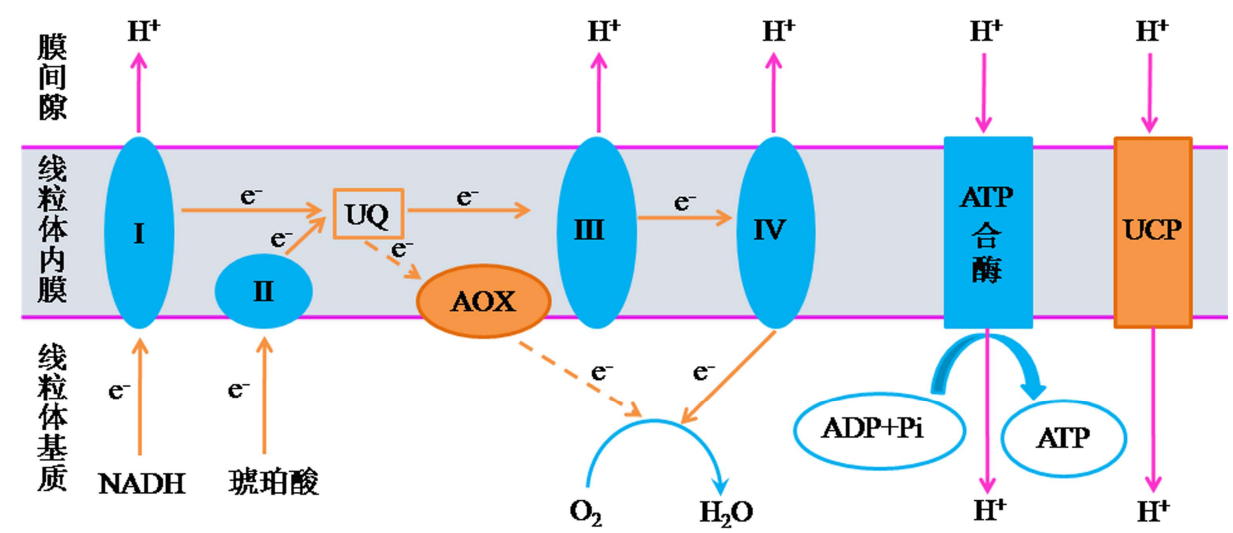

图 4 (网络版彩色)植物线粒体中的电子传递链与能量产生. 在电子传递链主路, 即细胞色素途径中, 电子由三羧酸循环的中间产物NADH和 琥珀酸分别传递至电子传递复合体 I (complex I) 和复合体 II (complex II), 再传递至泛醌(ubiquinone, UQ), 之后分别经过复合体 III (complex III) 和复合体 IV (complex IV), 最终传递至 $\mathrm{O}_{2}$, 形成 $\mathrm{H}_{2} \mathrm{O}$. 而在电子传递链支路, 即选择性呼吸途径, 电子经由泛醌(UQ)传递至交替氧化酶 (alternative oxidase, AOX), 再传递至 $\mathrm{O}_{2}$. 在电子传递过程中, 线粒体基质中的 $\mathrm{H}^{+}$经由复合体 I, III, IV 原出至膜间隙, 从而形成跨膜电子势梯 度. 在呼吸作用的氧化磷酸化过程中, $\mathrm{H}^{+}$经由ATP合酶(ATPase)返回线粒体基质, 而ATPase将 $\mathrm{H}^{+}$释放的能量用于ATP的合成. 线粒体解偶联蛋 白(uncoupling protein, UCPs)的存在则可以将 $\mathrm{H}^{+}$从膜间隙返回线粒体基质的过程与ATP合成的过程解偶联，从而将大量的能量以热能的形式 释放

Figure 4 (Color online) Electron transport chain and energy production in plant mitochondria. In cytochrome c pathway, NADH and succinic acid transfer electrons to complex I and complex II respectively, and then transfer to the UQ pool. Electrons in UQ are then passed to complex III, cytochrome $\mathrm{c}$ and finally complex $\mathrm{IV}$, which catalyzes the reduction of $\mathrm{O}_{2}$ to $\mathrm{H}_{2} \mathrm{O}$. But in another branch pathway, electrons flow from UQ to AOX corresponds with the reduction of $\mathrm{O}_{2}$ to $\mathrm{H}_{2} \mathrm{O}$. During the process of oxidative phosphorylation, $\mathrm{H}^{+}$is translocated to inner membrane space of mitochondria via ATPase and proton motive force is used to generate ATP. The presence of UCPs can uncouple the transmembrane of $\mathrm{H}^{+}$with ATP synthesis, and energy release as heating 
包含 4 个谷氨酸和 2 个组氨酸的铁离子结合域 ${ }^{[33]}$. 通 过点突变的遗传学研究, 人们已经鉴定了AOX蛋白 中具有催化活性的关键残基 ${ }^{[34]}$. 并且, 电子顺磁共 振技术(electron paramagnetic resonance, EPR)和傅里 叶变换红外光谱(fourier transform infrared spectroscopy, FTIR)等显微镜技术已经证实了AOX蛋白的双 核铁中心区域确实能够将 $\mathrm{O}_{2}$ 还原成 $\mathrm{H}_{2} \mathrm{O}^{[35,36]}$. 此外, 人们还鉴定出了AOX蛋白的一些用于结合泛醌的残 基 ${ }^{[37,38]}$. AOX在细胞中以二聚体的形式存在, 其活性 受到二硫键的氧化还原调节, 在还原状态下具有活 性, 而在氧化状态下不具活性 ${ }^{[39]}$. 由于电子传递链 $\mathrm{AOX}$ 途径中, 只有电子经过复合体 I 时有质子被洜 出至线粒体膜间隙, 不利于线粒体的跨膜质子电化 学势梯度的建立, 仅能产生少量的ATP, 而大量能量 以热能的形式释放. 在正常状态下, 植物体内 $\mathrm{AOX}$ 蛋白的表达水平并不高; 而在寒冷、损伤、干旱等逆 境胁迫下, AOX则会大量表达 ${ }^{[40]}$. 这些研究表明 $\mathrm{AOX}$ 在植物抵抗环境胁迫方面可能发挥着重要的 作用.

氧气同位素分离(oxygen isotope discrimination) 和GC-MS分析已经表明在荷花(N. nucifera) 中, AOX 介导的呼吸途径在花部生热前后发生了显著变 化 ${ }^{[41,42]}$. 在荷花花部温度与环境温度相差不大时 $\left(16^{\circ} \mathrm{C}\right.$ 以下), AOX途径不明显. 但是当花部温度高于 环境温度 $16^{\circ} \mathrm{C}$ 以上时, $\mathrm{AOX}$ 途径的呼吸作用显著增 强, 在生热最高峰时 AOX途径所占总呼吸作用的比 重达到 $75 \%$. 而在整个生热过程中, 细胞色素途径的 呼吸作用却没有发生明显的变化 ${ }^{[41]}$. 随后, Grant等 人 $^{[42]}$ 通过分离线粒体蛋白和免疫印迹(immunoblot) 的方法发现在AOX蛋白的表达量在生热开始时急速 上调, 而在生热过程中则维持在一个稳定的水平. 由 此可见, AOX蛋白与荷花的开花生热有关.

然而, 随着研究的不断深人, 研究者发现植物线 粒体解偶联蛋白 (uncoupling proteins, UCPs)也与植物 的开花生热有关, AOX调控植物开花生热的理论开 始受到挑战 ${ }^{[43,44]}$. UCPs 是位于线粒体内膜上的一类 转运蛋白, 在真核生物中广泛存在, 在呼吸代谢中, 其通过脂肪酸将 $\mathrm{H}^{+}$从膜间隙转运到线粒体基质中 ${ }^{[45]}$, 能够解除电子传递链与 ATP合成之间的偶联关系, 从而使氧化磷酸化反应中原本用于ATP合成的能量 以热能的形式释放出来 ${ }^{[46,47]}$. 目前, 在动物组织中已 经发现 5 种 UCP亚型：UCP1, UCP2, UCP3, UCP4,
$\mathrm{UCP} 5^{[45]}$. 在动物棕色脂肪组织中, UCP的解偶联作 用对生热以及热能的释放起着重要的调控作 用 ${ }^{[44,47,48]}$. 而UCP蛋白在植物的大部分组织中均有表

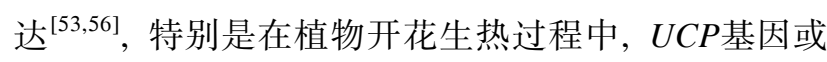
者蛋白的表达量表现出显著上升, 如裂叶喜林芋 $(P$. selloum $)$ 和臭菘属的肾叶臭菘 $(\text { S. renifolius })^{[49,50]}$. 这 些结果表明UCP蛋白也有可能参与调控植物的开花 生热. 然而到目前为止, 在植物开花生热过程中, 尚 不清楚AOX和UCP蛋白的调控作用之间的关系. 有 假说认为 $\mathrm{AOX}$ 或者 UCP蛋白对开花生热的调控作用 取决于花器官呼吸代谢的底物. 如果呼吸代谢底物 为糖类, 则可能是 $\mathrm{AOX}$ 起作用; 如果为脂类, 则可能 是UCP起调控作用 ${ }^{[50]}$, 然而目前并没有得到证实.

近年来, 高通量测序技术的发展使研究者们能 够更加深人地了解开花生热的复杂调控网络. 通过 superSAGE测序, 研究者发现在生热植物肾叶臭菘 (S. renifolius) 中, 开花生热时和生热之后, 花器官的 基因表达发生了显著改变 ${ }^{[51]}$. 最重要的是, 与生热 之后 (post-thermogenic) 的花器官相比, 生热阶段 (thermogenic)的花器官中, 大量与细胞呼吸、线粒体 功能以及线粒体合成有关的基因显著上调表达 ${ }^{[51]}$. 因此, 细胞呼吸作用的增强可能在短期的植物生热 中发挥作用. 由于生热调控类型的植物开花生热在 整个花期一直持续, 这一长期的生热过程中, 线粒体 的大量合成可能也扮演着重要角色 ${ }^{[51]}$.

近期, 本研究组还通过高通量测序发现 miRNA 在植物的开花生热中也起着重要的调控作用. miRNA是一类21 25 nt的非编码RNA, 在植物中通过切 割mRNA而调控靶基因表达水平, 参与调控植物的 生长发育、细胞分化、开花、抗病毒和胁迫响应等多 种生理过程 ${ }^{[52 \sim 55]}$. 通过 miRNA测序技术, 在玉兰花 中鉴定了114条miRNA, 并且发现17条miRNA在非生 热时期(花蕾期)和生热时期(雌荵期, 雄芯期)的表达 量有显著差异, 表明这些序列与生热过程密切相关. 更进一步发现，这些与生热有关的miRNA靶基因主 要与聚戊烯基转移酶激活和光合电子传递有关. 聚 戊烯基转移酶位于植物线粒体中, 能限制辅酶 $\mathrm{Q}$ 的生 物合成, 而辅酶 $\mathrm{Q}$ 是产生ATP的呼吸链上重要的组成 部分, 因此, miRNA可能通过限制辅酶Q的生物合成 而降低ATP的合成, 从而利于能量以热能形式释 放 ${ }^{[56]}$. 此外, 这些生热有关的 miRNA靶基因也与光 合电子传递有关. 这表明在节律性生热的假生热调 
控类型中, miRNA也可能通过调控花器官的光反应 (light response)而调控其开花生热 ${ }^{[56]}$. 总之, 这些研究 结果都表明植物的开花生热可能涉及极其复杂的调控 网络, 亟待进一步的深人研究来揭开其神秘面纱.

\section{4 总结与展望}

通过大量的研究, 人们已经对于植物开花生热 的功能及其调控有了一定程度的了解, 但是依然有 许多问题亟待解决. 尽管研究者已经鉴定了AOX和 UCP两个与植物开花生热有关的重要调控蛋白, 然 而这两个蛋白在开花生热过程中的作用及其相互关 系还不清楚. 此外, 线粒体作为动植物呼吸和能量代 谢的重要场所, 在开花生热的能量供应中扮演着怎
样的角色，目前，叹需发展新技术和新方法在活体状 态下研究AOX, UCP以及线粒体如何参与开花生热的 调控, 以及除线粒体之外是否有其他的生热途径也 值得探究. 并且, 开花生热的植物包含两种不同的生 热类型, 即生热调控和假生热调控, 这两种生热类型 的调控机理是否存在差异, 以及这些差异又表现在 哪些方面, 都是亟需解决的问题. 此外, 生热调控和 假生热调控的花朵在植物-昆虫互作中的能量消耗也 具有显而易见的差异. 这些差异的生热类型也可能 与植物-昆虫协同进化过程有关. 而在这协同进化过 程中，哪些基因参与这个过程? 这些基因的系统分 布和演化规律如何? 这些问题在将来的植物开花生 热研究中都是需要重点关注的科学问题.

致谢感谢北京林业大学林金星教授以及北京大学贺新强教授在文稿撰写中提出的宝贵建议.

\section{参考文献}

1 Huang S Q, Sun S G, Takahashi Y, et al. Gender variation of sequential inflorescences in a monoecious plant Sagittaria trifolia (Alismataceae). Ann Bot, 2002, 90: 613-622

2 Seymour R S, Ito Y, Onda Y, et al. Effects of floral thermogenesis on pollen function in Asian skunk cabbage Symplocarpus renifolius. Biol Lett, 2009, 5: 568-570

3 Wang R H, Zhang Z X. Perspectives and research advances on the thermogenesis (in Chinese). Guihaia, 2011, 3: 407-413 [王若涵, 张志 翔. 开花生热效应研究进展. 广西植物, 2011, 3: 407-413]

4 Seymour R S, Lindshau G, Ito K. Thermal clamping of temperature-regulating flowers reveals the precision and limits of the biochemical regulatory mechanism. Planta, 2010, 231: 1291-1300

5 Seymour R S, Schultze-Motel P. Heat-producing flowers. Endeavour, 1997, 21: 125-129

6 Miller R E, Grant N M, Giles L, et al. In the heat of the night-alternative pathway respiration drives thermogenesis in Philodendron bipinnatifidum. New Phytol, 2011, 189: 1013-1026

7 Li J K, Huang S Q. Flower thermoregulation facilitates fertilization in Asian sacred lotus. Ann Bot, 2009, 103: 1159-1163

8 Gibernau M, Seymour R S, White C R. Environmental biology: Heat reward for insect pollinators. Nature, 2003, 426: 243-244

9 Suinyuy T N, Donaldson J S, Johnson S D. Patterns of odour emission, thermogenesis and pollinator activity in cones of an African cycad: What mechanisms apply? Ann Bot, 2013, 112: 891-902

10 Wang R H, Xu S, Liu X Y, et al. Thermogenesis, flowering and the association with variation in floral odour attractants in Magnolia sprengeri (Magnoliaceae). PLoS One, 2014, 9: e99356

11 Bermadinger-Stabentheiner E, Stabentheiner A. Dynamics of thermogenesis and structure of epidermal tissues in inflorescences of Arum maculatum. New Phytol, 1995, 131: 41-50

12 Vollmer M, Möllmann K P. Infrared Thermal Imaging: Fundamentals, Research and Applications. New York: John Wiley and Sons Ltd, 2010

13 Skubatz H, Nelson T, Dong A, et al. Infrared thermography of Arum lily inflorescences. Planta, 1990, 182: 432-436

14 Wang R H, Liu X Y, Mou S L, et al. Temperature regulation of floral buds and floral thermogenicity in Magnolia denudata (Magnoliaceae). Trees, 2013, 27: 1755-1762

15 Barthlott W, Szarzynski J, Vlek P, et al. A torch in the rain forest: Thermogenesis of the titan arum (Amorphophallus titanum). Plant Biol, 2009, 11: 499-505 
16 Ivancic A, Roupsard O, Garcia J Q, et al. Thermogenesis and flowering biology of Colocasia gigantea, Araceae. J Plant Res, 2008, 121: $73-82$

17 Wang R H, Zhang Z X. Floral thermogenesis: An adaptive strategy of pollination biology in Magnoliaceae. Commun Integr Biol, 2015, 8: e992746

18 Lamprecht I, Seymour R S, Schultze-Motel P. Direct and indirect calorimetry of thermogenic flowers of the sacred lotus, Nelumbo nucifera. Thermochim Acta, 1998, 309: 5-16

19 Seymour R S. Pattern of respiration by intact inflorescences of the thermogenic arum lily Philodendron selloum. J Exp Bot, 1999, 50: $845-852$

20 Seymour R S. Dynamics and precision of thermoregulatory responses of eastern skunk cabbage Symplocarpus foetidus. Plant Cell Environ, 2004, 27: 1014-1022

21 Seymour R S, Schultze-Motel P. Respiration, temperature regulation and energetics of thermogenic inflorescences of the dragon lily Dracunculus vulgaris (Araceae). Proc Roy Soc B-Biol Sci, 1999, 266: 1975

22 Ito K, Abe Y, Johnston S D, et al. Ubiquitous expression of a gene encoding for uncoupling protein isolated from the thermogenic inflorescence of the dead horse arum Helicodiceros muscivorus. J Exp Bot, 2003, 54: 1113-1114

23 Seymour R S, Silberbauer-Gottsberger I, Gottsberger G. Respiration and temperature patterns in thermogenic flowers of Magnolia ovata under natural conditions in Brazil. Funct Plant Biol, 2010, 37: 870-878

24 Gottsberger G, Silberbauer-Gottsberger I, Seymour R S, et al. Pollination ecology of Magnolia ovata may explain the overall large flower size of the genus. Flora, 2012, 207: 107-118

25 Dieringer G, Lara M, Loya L. Beetle pollination and floral thermogenicity in Magnolia tamaulipana (Magnoliaceae). Int J Plant Sci, 1999, 160: 64-71

26 Kumano-Nomura Y, Yamaoka R. Beetle visitations, and associations with quantitative variation of attractants in floral odors of Homalomena propinqua (Araceae). J Plant Res, 2009, 122: 183-192

27 Thien L B, Bernhardt P, Devall M S, et al. Pollination biology of basal angiosperms (ANITA grade). Am J Bot, 2009, 96: 166-182

28 Nagy K A, Odell D K, Seymour R S. Temperature regulation by the inflorescence of philodendron. Science, 1972, 178: 1195-1197

29 Meeuse B J D, Raskin I. Sexual reproduction in the arum lily family, with emphasis on thermogenicity. Sex Plant Repord, 1988, 1: 3-15

30 Vanlerberghe G C, Mcintosh L. Alternative oxidase: From gene to function. Annu Rev Plant Physiol Plant Mol Biol, 1997, 48: 703-734

31 Rasmusson A G, Fernie A R, Dongen J T. Alternative oxidase: A defence against metabolic fluctuations? Physiol Plant, 2009, 137: 371-382

32 Liang Z. The cyanide elctron transport chain in plant mitochondria (in Chinese). Plant Physiol Commun, 1985, 5: 1-9 [梁峥. 植物线粒体 抗氧电子传递链. 植物生理学通讯, 1985, 5: 1-9]

33 Berthold D A, Stenmark P. Membrane-bound diiron carboxylate proteins. Annu Rev Plant Biol, 2003, 54: 497-517

34 Albury M S, Affourtit C, Crichton P G, et al. Structure of the plant alternative oxidase: Site-directed mutagenesis provides new information on the active site and membrane topology. J Biol Chem, 2002, 277: 1190-1194

35 Berthold D A, Voevodskaya N, Stenmark P, et al. EPR studies of the mitochondrial alternative oxidase: Evidence for a diiron carboxylate center. J Biol Chem, 2002, 277: 43608-43614

36 Moore A L, Carré J E, Affourtit C, et al. Compelling EPR evidence that the alternative oxidase is a diiron carboxylate protein. Biochim Biophys Acta, 2008, 1777: 327-333

37 Moore A L, Albury M S. Further insights into the structure of the alternative oxidase: From plants to parasites. Biochem Soc Trans, 2008, 36: $1022-1026$

38 Albury M S, Elliott C, Moore A L. Ubiquinol-binding site in the alternative oxidase: Mutagenesis reveals features important for substrate binding and inhibition. Biochim Biophys Acta, 2010, 1797: 1933-1939

39 Affourtit C, Albury M S, Crichton P G, et al. Exploring the molecular nature of alternative oxidase regulation and catalysis. FEBS Lett, 2002, 510: 121-126

40 Juszczuk I M, Rychter A M. Alternative oxidase in higher plants. Acta Biochim Pol, 2003, 50: 1257-1271

41 Watling J R, Robinson S A, Seymour R S. Contribution of the alternative pathway to respiration during thermogenesis in flowers of the sacred lotus. Plant Physiol, 2006, 140: 1367-1373

42 Grant N M, Miller R E, Watling J R, et al. Synchronicity of thermogenic activity, alternative pathway respiratory flux, AOX protein content, and carbohydrates in receptacle tissues of sacred lotus during floral development. J Exp Bot, 2008, 59: 705-714

43 Chaimovich H, Martins L S, Silva M P, et al. PUMPing plants. Nature, 1995, 375: 24

44 Laloi M, Klein M, Riesmeier J W, et al. A plant cold-induced uncoupling protein. Nature, 1997, 389: 135-136

45 Ricquier D, Bouillaud F. The uncoupling protein homologues: UCP1, UCP2, UCP3, StUCP and AtUCP. Biochem J, 2000, 345: 161-179 
Krauss S, Zhang C Y, Lowell B B. The mitochondrial uncoupling-protein homologues. Nat Rev Mol Cell Biol, 2005, 6: 248-261

Vercesi A E, Borecký J, Maia I D G, et al. Plant uncoupling mitochondrial proteins. Annu Rev Plant Biol, 2006, 57: 383-404

Cannon B, Nedergaard J. Brown adipose tissue: Function and physiological significance. Physiol Rev, 2004, 84: 277-359

Ito K, Seymour R S. Expression of uncoupling protein and alternative oxidase depends on lipid or carbohydrate substrates in thermogenic plants. Biol Lett, 2005, 1: 427-430

1911-1916

51 Ito-Inaba Y, Hida Y, Matsumura H, et al. The gene expression landscape of thermogenic skunk cabbage suggests critical roles for mitochondrial and vacuolar metabolic pathways in the regulation of thermogenesis. Plant Cell Environ, 2012, 35: 554-566

52 Qi L W, Li X M, Zhang S Z, et al. Genetic regulation of non-coding RNA (in Chinese). Sci China Ser C: Life Sci, 2006, 3: 193-208 [齐力 旺, Li X M, 张守攻, 等. 非编码蛋白 RNA 的遗传调控. 中国科学 C 辑：生命科学, 2006, 3: 193-208]

53 Xu Z H, Xie C X. Advances in plant microRNA and stresses response (in Chinese). Hereditas, 2010, 10: 1018-1030 [许振华, 谢传晓. 植 物 microRNA 与逆境响应研究进展. 遗传, 2010, 10: 1018-1030]

54 Zhu Q H, Helliwell C A. Regulation of flowering time and floral patterning by miR172. J Exp Bot, 2010, 62: 487-495

55 Curaba J, Spriggs A, Taylor J, et al. miRNA regulation in the early development of barley seed. BMC Plant Biol, 2012, 12: 120

56 Liu X Y, Cao D C, Ji X Y, et al. miRNAs play essential roles in the floral thermogenesis of Magnolia denudata (Magnoliaceae). Trees, 2015, 29: 35-42

\title{
Progress in biological functions and regulation mechanisms of floral thermogenesis
}

\author{
ZHANG ChuLan ${ }^{1,2}$, WANG RuoHan ${ }^{1}$, ZHANG ZhiXiang ${ }^{1,2}$ \& CHENG HePing ${ }^{3}$ \\ ${ }^{1}$ College of Biological Sciences and Biotechnology, Beijing Forestry University, Beijing 100083, China; \\ ${ }^{2}$ College of Nature Conservation, Beijing Forestry University, Beijing 100083, China; \\ ${ }^{3}$ Institute of Molecular Medicine, Peking University, Beijing 100871, China;
}

Floral thermogenesis, which has been developed during the long history of evolution, is an adaptive strategy of some plants. It is of crucial significance for ensuring reproduction success of thermogenic plants, since it avoids cold damage to flowers and plays a critical role in attracting pollinators and promoting pollination. Based on recent research progress on thermogenesis at home and abroad, we summarized patterns, biological functions, and underlying regulatory mechanisms of floral thermogenesis, by referring to emerging techniques of real time and in vivo investigation into floral thermogenesis. Finally, we concluded by highlighting several outstanding biological questions that need to be addressed for further advance understanding in this research field.

floral thermogenesis, infrared thermography, alternative oxidase (AOX), uncoupling protein (UCP), miRNA doi: 10.1360/N972015-00755 